\title{
Leave no woman behind, Ethiopia: Baseline report
}

\author{
Annabel Erulkar \\ Population Council \\ Tekle-Ab Mekbib \\ Population Council \\ Helen Amdemikael \\ Garry Conille
}

Follow this and additional works at: https://knowledgecommons.popcouncil.org/departments_sbsr-pgy

Part of the Demography, Population, and Ecology Commons, Family, Life Course, and Society Commons, Gender and Sexuality Commons, International Public Health Commons, Maternal and Child Health Commons, Medicine and Health Commons, and the Women's Health Commons How does access to this work benefit you? Let us know!

\section{Recommended Citation}

Erulkar, Annabel, Tekle-Ab Mekbib, Helen Amdemikael, and Garry Conille. 2007. "Leave no woman behind, Ethiopia: Baseline report." Addis Ababa: Population Council. 


\section{Leave No Woman Behind ETHIOPIA}

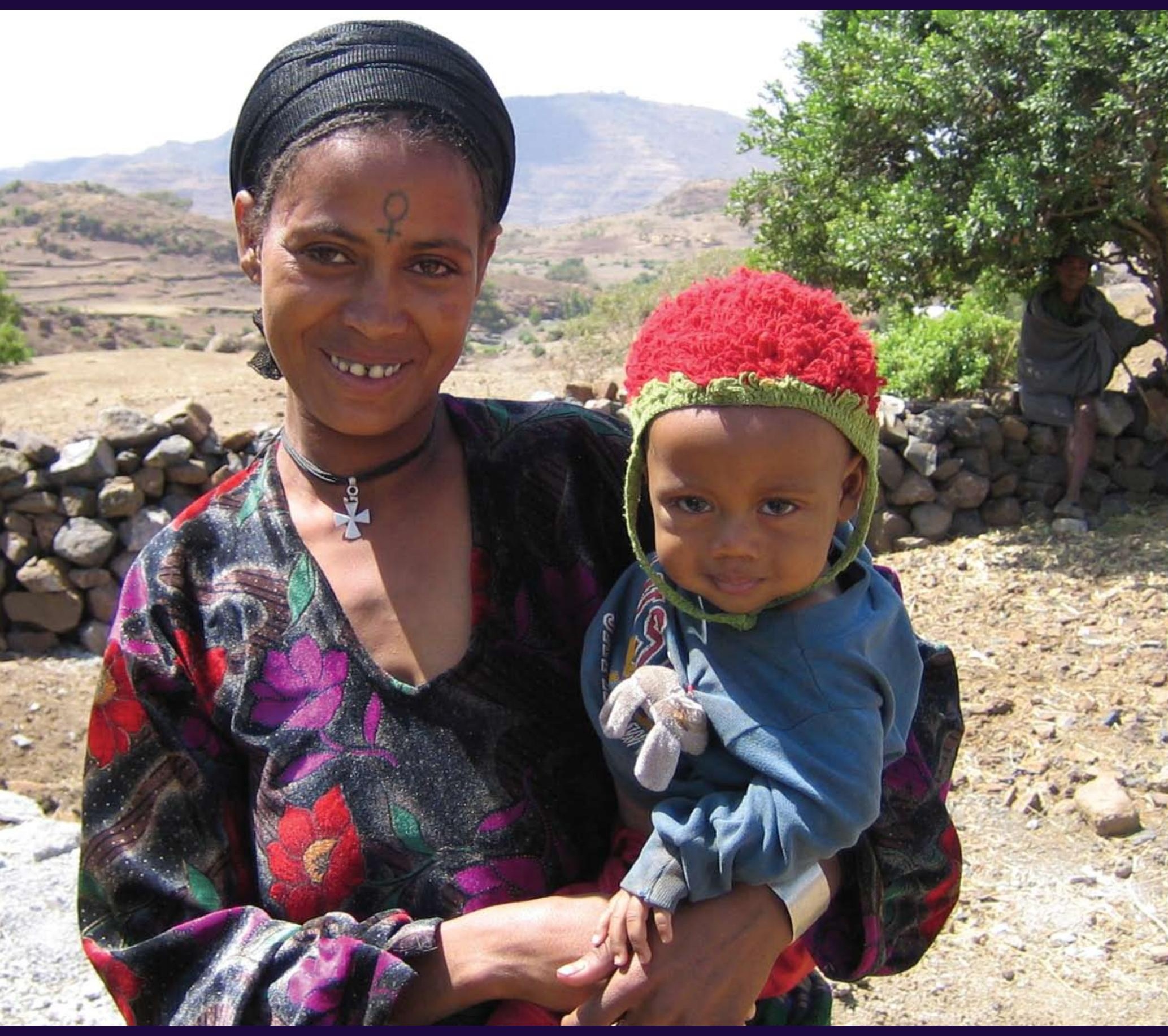





\title{
Leave No Woman Behind, Ethiopia
}

\section{Baseline Report}

\author{
Annabel S. Erulkar \\ Tekle Ab Mekbib \\ Helen Amdemikael \\ Garry Conille
}




\section{(1) Population Council}

The Population Council is an international, nonprofit, nongovernmental organization that seeks to improve the well-being and reproductive health of current and future generations around the world and to help achieve a humane, equitable, and sustainable balance between people and resources. The Council conducts biomedical, social science, and public health research and helps build research capacities in developing countries. Established in 1952, the Council is governed by an international board of trustees. Its New York headquarters supports a global network of regional and country offices.

(C) 2007 by The Population Council

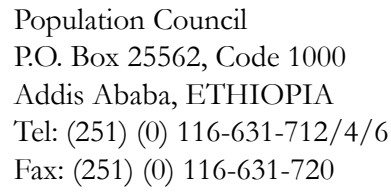

\author{
Population Council \\ One Dag Hammarskjold Plaza \\ New York, NY 10017 USA \\ Tel: $212-339-0500$ \\ Fax: 212-755-6052 \\ http://www.popcouncil.org
}

Annabel S. Erulkar, MSc, PhD is Senior Associate and Country Director at the Population Council's Ethiopia Office in Addis Ababa.

Tekle-Ab Mekbib, MD, PhD, is Medical Consultant for the Population Council in Addis Ababa, Ethiopia.

Helen Amdemikael, MA is Program Officer for Gender and Advocacy, UNFPA Ethiopia

Garry Conille, MD, MPH, Policy Advisor on Health, UNFPA, New York

Photo credits: 2005 Virginia Lamprecht, Courtesy of Photoshare

\section{ACKNOWLEDGEMENTS}

This study would not have been possible without the financial and technical support of UNFPA Country Office. We acknowledge the assistance and support of the Ministry of Youth and Sports, and the Amhara Regional Youth and Sports Bureau, as well as the Zonal Youth and Sports Office during the data collection phase. Negussie GebreTsadik coordinated all field work and numerous field supervisors and interviewers undertook data collection. We appreciate their hard work and dedication. Finally, we thank the adolescent girls and women from Yilimana Dinsa, Mecha and Achefer Woredas for sharing their time, ideas and experiences. 


\section{TABle of Contents}

Executive Summary ................................................................ vi

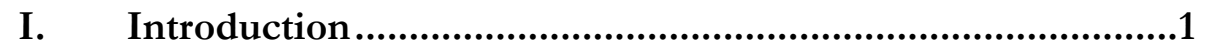

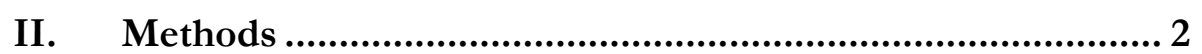

III. Sample \& Household Characteristics .................................. 2

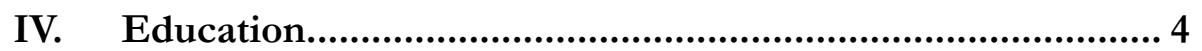

V. Work \& Livelihoods ....................................................... 6

VI. Community Participation, Social Support \& Networks........ 7

VII. Marriage \& Sexual Activity.............................................. 9

Attitudes toward marriage ..................................................................... 9

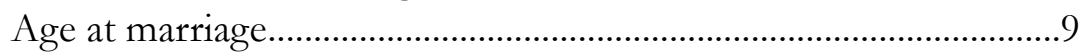

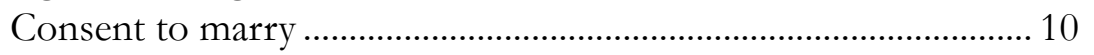

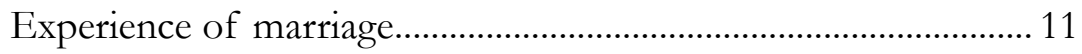

Divorce and remarriage.................................................................... 11

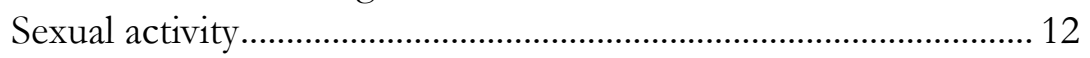

VIII. Attitudes Toward Health Issues .......................................13

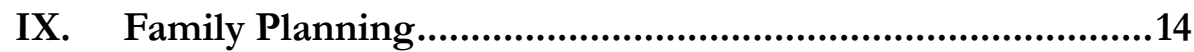

Awareness of family planning......................................................... 14

Family planning use .......................................................................... 14

Community and individual attitudes about fertility

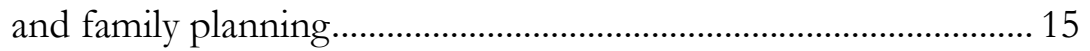

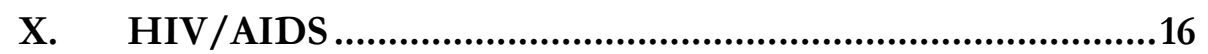

Knowledge of HIV/AIDS................................................................. 16

Personal experience with HIV/AIDS................................................ 16

Community and individuals attitude about HIV/AIDS ................ 16

XI. Maternal \& Child Health.....................................................18

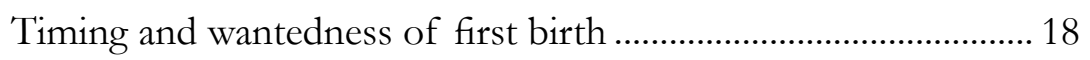

Care during pregnancy and delivery .............................................. 19

Community and individual attitudes toward pregnancy

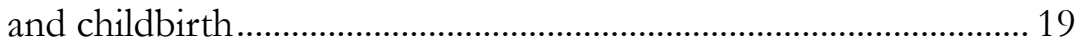

XII. Female Genital Cutting ................................................ 22

XIII. Exposure to Reproductive Health Messages ...................... 22 
XIV. Program Preferences

XV. Recommendations \& Implications for Programs .............. 25

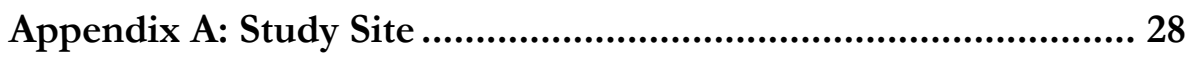

Appendix B: Household Assets .................................................. 28 


\section{Tables \& Figures}

Table 3.1: Sample characteristics of respondents, by woreda (district) 3

Table 4.1: Percentage of respondents who ever attended school and reasons for non-participation, by age group ..... 4

Table 4.2: Pattern of schooling among those who have attended,

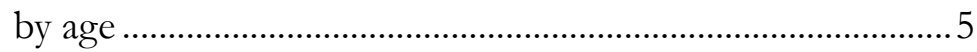

Table 5.1: Percentage of respondents who have ever worked, are currently working, and have savings, by age group and woreda

Table 6.1: Percentage of respondents participating in public events/activities in the last week, by age group.... 7

Table 6.2: Percentage of respondents who have non-familial friends to turn to in emergency or with problems, by age group. .8

Table 7.1: Ideal age at marriage for males and females, by age group, marital status \& education.

Figure 1: Cumulative proportion of respondents married by age and education

Table 7.2: Percentage of marriages that were arranged and with consent given, by age at marriage and age category...

Table 7.3: Respondents' relationship to current or most recent spouse (percentage agreeing with statements).

Table 7.4: 'Wantedness' of first sex, by age at first sex

Table 8.1: Percentage of respondents considering health issues a "big problem" in their community.

Table 9.1: Knowledge of family planning methods, by age group \& educational status.....

Table 9.2: Ever and current use of family planning among sexually active 
Table 9.3: Percentage of respondents agreeing with statements related to desired family size and family planning, by level of education and age group

Table 10.1: Knowledge about HIV/AIDS, by level of education and age group

Table 10.2: Percentage of respondents agreeing with statements related to HIV/AIDS, by level of education and age group

Table 10.3: Percentage of respondents holding negative views of HIV infected people, by level of education and age group

Table 11.1: Percentage of respondents who have given birth, relationship to father of child and desired number of children, by age group

Figure 2: Percentage of first births that are wanted, by age at first birth

Table 11.2: Care and delivery during first pregnancy, by level of education and age group

Table 11.3: Percentage of respondents agreeing with statements related to safe motherhood, by level of education and age group

Table 12.1: Prevalence of and attitudes toward female genital cutting, by educational level and age group

Table 13.1: Percentage of respondents hearing reproductive health messages in the last year, by topic and medium

Table 13.2: Percentage of respondents who discussed topics in the last year and discussion partners for topics.

Table 14.1: Percentage of respondents reporting that they would like classes in specific topics, by topic 24 


\section{Executive Summary}

Leave no women bebind is an experimental project being implemented in rural areas of Amhara region. The project uses mobilization of women into groups and adult literacy as an entry point for reproductive health education and referrals. Measurement of the program's impact is being undertaken using a quasi experimental research design including baseline and endline surveys in six Kebele Associations (KA's) in rural Amhara. This report describes the findings of the baseline survey conducted among over 3,000 girls and women aged 10 to 45 in rural Amhara region. Results are disaggregated by age group and education, with significant differences between sub-groups for many variables. The study is meant to add to the limited information available on life for rural girls and women in Ethiopia.

School attendance and educational attainment is exceedingly low, though attendance appears to be increasing. Among women aged 30 to 45, only 8 percent have ever attended school, while 38 percent of girls aged 10 to 19 have attended. Even among those attending, attainment is very low. Women attended school, on average, for only 3.7 years and among those who attended, only 7 percent completed 8 years of education. The main reasons for not attending school were that parents did not see the benefit and early marriage.

Respondents in the study had extremely limited social networks and social support outside their families. This is particularly true for adolescent girls. Less than one third of girls aged 10 to 19 had someone to turn to in the event of family or marriage problems, if they needed food, money or a place to stay, or in the event of rape. In fact, few respondents of any age reported having someone they could confide in if they were raped.

In the views of respondents, the ideal age at marriage for girls was relatively low: 16 years for girls, compared to 20 for boys. Fully 19 percent of respondent felt that girls should marry before the age of 15 . These ideals also reflected the experiences of respondents themselves, with median age at marriage being 17 among those aged 10 to 19, 14 among those 20 to 29 , and 13 among respondents aged 30 and above. The vast majority of marriages were arranged and very few included consent from the child bride. Most respondents first had sex within the context of marriage, meaning the timing of first sex and first birth was mainly driven by the timing of marriage.

Most respondents were aware of three modern family planning methods, pills, depo, and condoms. However, use of family planning was very low. Among sexually active women, only 13 percent were using a method. The low use of family planning could be linked to community attitudes on fertility or husband's disapproval. A large proportion of respondents felt 
that women should have 'extra' children in case some died in childbirth and to ensure that she is cared for during old age. Two thirds felt that the number of children a woman has is "up to God" and one third reported that their husbands disapprove of family planning.

With high rates of HIV / AIDS in Amhara region, 19 percent of respondents know of someone who has died of AIDS, most of whom are described as neighbors or acquaintances. However, few respondents consider themselves at personal risk of contracting HIV, with 92 percent considering themselves at no risk whatsoever. Few respondents feeling at risk could be related to misconceptions they have regarding HIV. For example, a large proportion of respondents felt that HIV was a disease transmitted in towns, not rural areas. Though individually, respondents reported wanting to be tested for HIV, they feared rejection of their community and of their husbands. Over half of the respondents did not want to know their status because of the fear of community rejection. Stigma seemed to be a valid fear as respondents, themselves, held stigmatizing views of people living with HIV. Nearly 80 percent would not be willing to share food or care for a person who was HIV +.

One out of six respondents had given birth by age 15 and two thirds had given birth by age 18. Most respondents delivered at their mothers' houses (70 percent), and the most common person attending the delivery was the respondent's mother ( 34 percent), followed by a traditional birth attendant (31 percent). Home birth seems to be supported by community values with most respondents feeling that the community and their husbands prefer birth at home compared to the clinic. In addition, the majority (71 percent) feel that if a woman dies in childbirth it is an unpreventable act of God and 21 percent feel that delivery in a clinic can lead to fistula.

A fairly substantial proportion of respondents (64 percent) have received reproductive health messages or information in the last year. Community lectures are the most common source of information and HIV/AIDS is the most common topic discussed. At the same time, interpersonal discussion of these topics is quite low. Only 18 percent of respondents have discussed HIV or family planning with their spouse in the last year. In fact, respondents seem more likely to discuss reproductive health issues with their female friends rather than with their spouses.

When asked the type of programs they would like for women in their area, most respondents reported literacy (54 percent), followed by HIV/AIDS (41 percent), and business training (39 percent). Most respondents said they would be able to attend such classes once or twice a week. 


\section{INTRODUCTION}

Leave No Woman Bebind (LNWB) is an innovative project that addresses women's skills, schooling and ability to manage reproductive health in rural areas of Amhara Region, Ethiopia. The project reaches out to women aged 10 to 45 , encouraging them to form women's groups through which nonformal education and reproductive health $(\mathrm{RH})$ education is passed. The intervention will take place in selected areas of Amhara region, Ethiopia, the most populous region in the country, where contraceptive prevalence is low, early marriage and early first birth are common and where HIV prevalence rates are among the highest in the country.

LNWB is an experimental intervention that includes a research component to measure changes associated with the project. The research is based on a quasi-experimental design where baseline and endline surveys will be undertaken in experimental and control areas. The design allows project managers to measure change associated with the project, while controlling for exogenous changes unrelated to project activities.

This report presents findings from the baseline survey conducted among over 3,000 girls and women aged 10 to 45 . The results cover a broad range of topics including education, work and livelihoods, social networks, reproductive health, exposure to $\mathrm{RH}$ messages and program preferences, and are meant to contribute to the limited information on the lives of rural women in Ethiopia today.

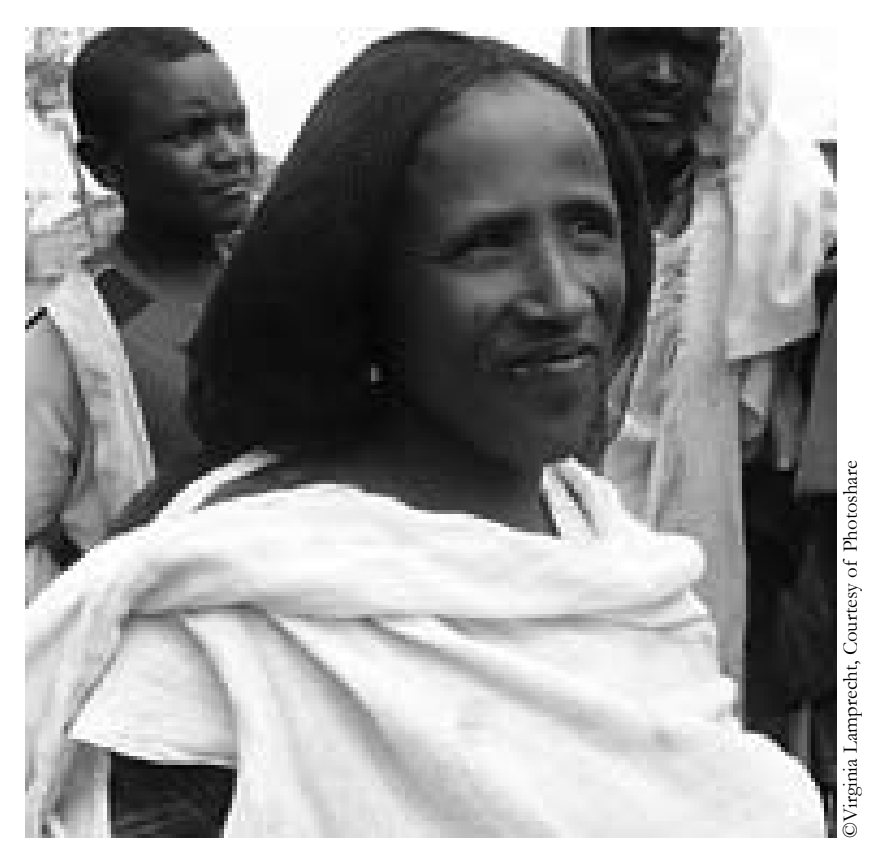




\section{Methods}

This is a quasi-experimental research design, which includes experimental and control sites surveyed at baseline, before project activities begin, and at endline, after several years of activities have been undertaken. The pilot project will take place in two rural Kebele Associations (KA) in two Woredas (districts) in Amhara region, with two other sites in the same districts serving as controls (see Appendix A. Study sites). Controls are selected to be comparable to experimental sites in terms of population size and infrastructure available, such as schools and health facilities. In addition, control areas are selected not to be adjacent to experimental areas, in order to control for potential contamination.

A household listing was conducted in the selected KA's that allowed researchers to identify eligible respondents. All households were assigned a household number and household residents were listed according to age and gender. A household was considered eligible for selection if there was at least one female resident aged 10 to 45 . All eligible households were entered in the computer and 800 households were randomly selected in intervention KA's while 400 households were randomly selected in control PA's. Where a selected household had more than one eligible woman, a Kish grid was used to select just one respondent.

Selected respondents were interviewed using a largely close-ended questionnaire. Female interviewers were trained for one week on administration of the questionnaire. Field supervisors oversaw the completeness and quality of the data. Data was analyzed using SPSS.

This report reflects results from the baseline survey. The report attempts to describe women in rural Amhara region in the broadest sense, including education, time use, work and livelihoods, social networks, access to RH information, and RH knowledge, attitudes and practice. Because of the wide age range of respondents, results are broken down by age group and, at times, by education and/or marital status. This report is meant to give a picture of women in the pilot sites and therefore does not disaggregate the sample by KA or by intervention versus control site.

\section{Sample Characteristics}

In all, 3,223 girls and women aged 10 to 45 were interviewed in the three study woredas, amounting to a 90 percent response rate.

The study population was homogeneous in terms of religion and ethnicity with virtually all respondents being Amhara and Orthodox Christians. Nearly three quarters of respondents (73 percent) had never been to school. Nearly two thirds of respondents (64 percent) were currently married and one quarter had never been married. 
Table 3.1: Sample characteristics of respondents, by woreda (district)

\begin{tabular}{|c|c|c|c|c|c|}
\hline & Category & $\begin{array}{l}\text { Yilimana Densa } \\
\qquad(\mathrm{n}=1088)\end{array}$ & $\begin{array}{l}\text { Mecha } \\
(n=1063)\end{array}$ & $\begin{array}{l}\text { Achefor } \\
(n=1072)\end{array}$ & $\begin{array}{c}\text { All } \\
(n=3223)\end{array}$ \\
\hline \multirow[t]{4}{*}{ Age group } & 10 to 19 & 33.1 & 30.9 & 33.7 & 32.5 \\
\hline & 20 to 29 & 37.1 & 41.6 & 34.9 & 37.9 \\
\hline & 30 to 39 & 20.6 & 18.7 & 21.4 & 20.3 \\
\hline & 40 to 45 & 9.2 & 8.8 & 10.0 & 9.3 \\
\hline \multirow[t]{2}{*}{ Religion } & Orthodox Christian & 98.9 & 99.7 & 99.7 & 99.4 \\
\hline & Other & 1.1 & 0.3 & 0.3 & 0.6 \\
\hline \multirow[t]{2}{*}{ Ethnicity } & Amhara & 99.9 & 99.7 & 100.0 & 99.9 \\
\hline & Other & 0.1 & 0.3 & 0.0 & 0.01 \\
\hline \multirow[t]{2}{*}{ Ever attended school } & No & 69.0 & 77.5 & 71.4 & 72.6 \\
\hline & Yes & $31.0^{\star \star \star}$ & 22.5 & 28.6 & 27.4 \\
\hline \multirow[t]{4}{*}{ Current marital status } & Never married & 25.7 & 22.5 & 25.0 & 24.4 \\
\hline & Currently married & $56.5^{\star * \star}$ & 66.8 & 69.1 & 64.1 \\
\hline & Divorced/ Separated & 13.8 & 7.5 & 3.8 & 8.4 \\
\hline & Widowed & 4.0 & 3.2 & 2.1 & 3.1 \\
\hline \multicolumn{2}{|c|}{ Mean number of household members } & 4.4 & 4.7 & 5.4 & 4.9 \\
\hline \multirow[t]{2}{*}{ Socio economic index } & Low (0 to 5 assets) & 49.7 & 39.1 & 32.9 & 40.6 \\
\hline & High (6 to 15 assets) & 50.3 & 60.9 & 67.1 & 59.4 \\
\hline
\end{tabular}

${ }^{* * \star}$ Differences between groups significant at $p<0.001$

There were differences between districts in terms of school attendance and marital status. Women in Yilimana Densa Woreda were significantly more likely to have attended school than respondents in the other two regions. In addition, women in Yilimana Densa are less likely to be married, with a large proportion being divorced (14 percent).

Households of respondents included roughly five members, with Achefor households having slightly more members (mean 5.4) compared to Yilimana Densa households (mean 4.4). Household socio-economic status was measured by asking respondents if their household possessed or owned specific items ${ }^{1}$ including electricity, radio, a bed or table, a kerosene lamp, crop land, cattle, cash crops, etc. Among the 15 items listed, households possessed an average of six items with the most common possessions being a kerosene lamp (95 percent), the house they live in (94 percent), crop land (85 percent) and cattle (75 percent). Respondents were scored

${ }^{1}$ Items mentioned were derived from the Ethiopia DHS (2000). 
I remember the day they made me cry. I begged my family to send me to school

but they didn't accept. I remember I cried bitterly that day.

- Age 16, no education, never been married, never had sex as to how many assets their household possessed or owned and then categorized as "high" socio-economic status for those possessing six to 15 assets, or "low" socio-economic status, having five or fewer household assets. A larger percentage of residents of Achefor were categorized as "high" economic status compared to residents of Yilimana Densa. On the other hand, residents of Achefor tended to possess items associated with a rural economy such as crop land, cattle, or horse/donkey/mule/oxen, while residents of Yilimana Densa and Mecha possessed items associated with modernity such as a roof of corrugated iron, or a pit latrine (see Appendix B: Household assets).

\section{Education}

The expansion of education over successive cohorts of women in the study is striking, as are the evolving barriers to education (Table 4.1). While 96 percent of women in the oldest age group (age 40 to 45) have never been to school, 38 percent of girls in the cohort 10 to 19 have never attended.

Table 4.1: Percentage of respondents who ever attended school and reasons for nonparticipation, by age group

\begin{tabular}{|c|c|c|c|c|c|}
\hline & $\begin{array}{l}10 \text { to } 19 \\
(n=1049)\end{array}$ & $\begin{array}{l}20 \text { to } 29 \\
(n=1219)\end{array}$ & $\begin{array}{l}30 \text { to } 39 \\
(n=652)\end{array}$ & $\begin{array}{l}40 \text { to } 45 \\
(n=301)\end{array}$ & $\begin{array}{c}\text { All } \\
(n=3221)\end{array}$ \\
\hline \multicolumn{6}{|l|}{ Ever attended school } \\
\hline Yes & 61.6 & 13.0 & 10.1 & 4.0 & 27.4 \\
\hline No & $38.4^{* * *}$ & 87.0 & 89.9 & 96.0 & 72.6 \\
\hline \multicolumn{6}{|c|}{ Main reason for not attending school } \\
\hline Parents don't see the benefit & 24.6 & 28.2 & 33.4 & 39.6 & 30.3 \\
\hline Got married & 21.9 & 28.9 & 28.8 & 25.0 & 27.2 \\
\hline Family could not afford & 28.4 & 24.1 & 20.4 & 14.2 & 22.7 \\
\hline Too many domestic duties & 15.7 & 12.4 & 8.4 & 5.6 & 11.1 \\
\hline School to far & 4.2 & 4.1 & 6.8 & 11.5 & 5.7 \\
\hline Other reasons & 5.2 & 2.3 & 2.2 & 4.1 & 3.0 \\
\hline
\end{tabular}

Overall, the main reason for women or girls not attending school was that their parents did not see the value in education (30 percent), followed by their having gotten married (27 percent). Reasons for not attending school varied by age cohort. Girls in the younger age cohorts were more likely than older respondents to cite poverty as the reason for not attending (28 percent among those aged 10 to 19; 24 percent among those aged 20 to 29). At the same time, older respondents mentioned the distance to school more often than younger respondents (12 percent of those aged 40 
to 45) which could reflect the smaller number of schools available when older women were of school-going age.

I remember the day they made me cry. I begged my family to send me to school but they didn't accept. I remember I cried bitterly that day. (Age 16, no education, never been married, never had sex)

Among those who have attended school, educational attainment is extremely low (Table 4.2). Women attended school, on average, for only 3.7 years. Only 7 percent of women who attended school had at least eight years of education. Most women entered school quite late (mean age at entry, 10 years), and age at school entry seemed to increase with age. Likewise, the older one was, the more likely that they participated in nonformal rather than formal education, with 45 percent of educated women in their 30's having attended non-formal schooling, compared to only 4 percent of girls aged 10 to 19. Among girls aged 10 to 19, 55 percent are currently attending school.

Table 4.2: Pattern of schooling among those who have attended, by age group

\begin{tabular}{|c|c|c|c|c|c|}
\hline & $\begin{array}{l}\text { Age } 10 \text { to } 19 \\
(n=636)\end{array}$ & $\begin{array}{l}\text { Age } 20 \text { to29 } \\
29(n=154)\end{array}$ & $\begin{array}{c}\text { Age } 30 \text { to } 39 \\
(n=65)\end{array}$ & $\begin{array}{l}\text { Age } 40 \text { to } 45 \\
(n=12)\end{array}$ & $\begin{array}{l}45 \text { All } \\
(n=867)\end{array}$ \\
\hline Mean years of education ${ }^{2}$ & 3.7 & 4.2 & 3.2 & 1.8 & 3.7 \\
\hline $\begin{array}{l}\text { Mean age at entry into school } \\
\text { Type of school attended }\end{array}$ & 9.1 & 10.9 & 12.5 & 13.8 & 9.7 \\
\hline Formal & 96.1 & 84.4 & 52.3 & 33.3 & 89.9 \\
\hline Non-formal & 3.6 & 12.3 & 44.6 & 66.7 & 9.1 \\
\hline Both formal and non-formal & 0.3 & 3.2 & 3.1 & 0.0 & 1.0 \\
\hline
\end{tabular}

Younger respondents were significantly more likely to be literate compared to older respondents. Forty-three percent of girls aged 10 to 19 reported that they can read "easily" compared to only 7 percent of 20 to 29 -year olds and 3 percent of those aged 30 or older.

${ }^{2}$ This calculation includes those who are currently in-school, which is a considerable proportion of 10 to 19 -yearolds. This implies that the ultimate educational attainment for 10 to 19 -year-olds is underestimated. 


\section{WORK \& LIVELIHOODS}

Only 15 percent of women in the sample have ever worked for pay and 12 percent are currently working. Few adolescents are working, only 5 percent, compared to older women (15 percent). Very few women have any savings, with less than 2 percent of the sample reporting any savings. Compared to women in Yilimana Densa and Mecha Woredas, few women in Achefor have ever worked for pay. Only 9 percent of Achefor women have ever worked for pay and only 7 percent are currently working.

Table 5.1: Percentage of respondents who have ever worked, are currently working, and have savings, by age group and woreda

\begin{tabular}{|c|c|c|c|c|c|c|c|}
\hline & $\begin{array}{l}10 \text { to } 19 \\
(n=1049)\end{array}$ & $\begin{array}{l}20 \text { to } 29 \\
\text { ( } n=1220)\end{array}$ & $\begin{array}{l}30 \text { to } 45 \\
(n=954)\end{array}$ & $\begin{array}{l}\text { Yilimana Densa } \\
\qquad(\mathrm{n}=1088)\end{array}$ & $\begin{array}{c}\text { Mecha Woreda } \\
\quad(n=1063)\end{array}$ & $\begin{array}{c}\text { Achefor Woreda } \\
(n=1072)\end{array}$ & $\begin{array}{c}\text { All } \\
(n=3223)\end{array}$ \\
\hline \multicolumn{8}{|c|}{ Ever worked for pay } \\
\hline Yes & 7.3 & 18.5 & 20.0 & 18.6 & 18.3 & 9.0 & 15.3 \\
\hline No & 92.7 & 81.5 & 80.0 & 81.4 & 81.7 & 91.0 & 84.5 \\
\hline \multicolumn{8}{|c|}{ Currently working for pay } \\
\hline Yes & 5.1 & 14.6 & 16.1 & 14.5 & 14.9 & 6.5 & 12.0 \\
\hline No & 94.9 & 85.4 & 83.9 & 85.8 & 85.1 & 93.5 & 88.0 \\
\hline \multicolumn{8}{|c|}{ Has savings } \\
\hline Yes & 1.6 & 1.9 & 1.7 & 2.5 & 1.0 & 1.7 & 1.8 \\
\hline No & 92.7 & 81.5 & 80.0 & 97.5 & 99.0 & 98.3 & 84.5 \\
\hline
\end{tabular}

The most common paid work was making areke or tella ${ }^{3}$ (among 42 percent of women who had ever worked for pay), followed by selling cereals (17 percent), domestic worker (10 percent), pottery (5 percent), sewing or weaving (4 percent) selling fruit and vegetables (4 percent) and trading in coffee or tea (4 percent). On average, women earned about 35 Birr (USD \$4.00) per week in paid work and worked 21 hours. The most lucrative work appeared to be making areke or engaged on domestic work, with women in this type of work making an average of about 40 Birr (USD \$5.00) per week. 


\section{Vi. Community Participation, Social Support \& Networks}

The vital registration system in the study areas was extremely weak, with only 22 respondents ( $<1$ percent) having a birth certificate and 62 respondents ( 2 percent) having a national identity card.

Respondents were asked a series of questions to assess the extent to which they participate in community events and the extent of their social support networks. Table 6.1 shows participation in community events and groups. The most common events or activities to have engaged in were participating in a coffee ceremony, going to a market, and attending Church / Mosque. For nearly all events mentioned, girls in the adolescent age group (10 to 19) were significantly less likely to have participated. Reasons for this could be due to younger girls more likely to be in school, rather than engaged in these activities, or on restrictions placed on their movements. Indeed, the younger a woman was, the more likely that she needed permission before leaving her house. Eighty-six percent of girls aged 10 to 19 needed permission before leaving the house, compared to 73 percent of women aged 20 to 29, 66 percent of women 30 to 39 and 55 percent of women 40 to 45 . At the same time, it is noteworthy that regardless of age group, women's movements are controlled and, even among the oldest women, over half need permission before leaving the house.

Table 6.1. Percentage of respondents participating in public events/activities in the last week, by age group

\begin{tabular}{|c|c|c|c|c|c|}
\hline & $\begin{array}{l}10 \text { to } 19 \\
(n=1049)\end{array}$ & $\begin{array}{l}20 \text { to } 29 \\
(n=1220)\end{array}$ & $\begin{array}{l}30 \text { to } 39 \\
(n=652)\end{array}$ & $\begin{array}{l}40 \text { to } 45 \\
(n=301)\end{array}$ & $\begin{array}{c}\text { All } \\
(n=3222)\end{array}$ \\
\hline $\begin{array}{l}\text { Participated in coffee } \\
\text { ceremony }\end{array}$ & $77.8^{\star * *}$ & 91.3 & 09.2 & 92.4 & 86.8 \\
\hline Gone to a market & $51.3^{* * *}$ & 80.7 & 83.1 & 80.1 & 71.6 \\
\hline Gone to a church/mosque & $11.0^{* * *}$ & 28.2 & 40.6 & 49.8 & 27.1 \\
\hline $\begin{array}{l}\text { Participated in idir/funeral } \\
\text { society }\end{array}$ & $6.9^{* * *}$ & 31.7 & 41.9 & 43.9 & 26.8 \\
\hline $\begin{array}{l}\text { Participated in women's group } \\
\text { meeting }\end{array}$ & 17.7 & $13.5^{\star}$ & 16.4 & 18.9 & 16.0 \\
\hline $\begin{array}{l}\text { Participated in an ekub/savings } \\
\text { circle }\end{array}$ & $2.5^{* * *}$ & 6.0 & 5.8 & 6.0 & 4.8 \\
\hline $\begin{array}{l}\text { Attended non-formal education } \\
\text { or literacy class }\end{array}$ & 4.4 & 2.8 & 2.0 & 3.3 & 3.2 \\
\hline
\end{tabular}

*** Differences between groups significant at $p<0.001$ 
Support networks were assessed by asking respondents a series of questions concerning support available from outside the immediate family, in the event of family emergency or problems (Table 6.2). On all the issues mentioned, less than half of respondents had a person or place to turn to outside the family in the event of a problem. It is noteworthy that the issue for which respondents reported the least support was in the event of rape, for which only 35 percent of respondents reported that they had someone to confide in if they were raped. Those with the fewest sources of support were girls aged 10 to 19. Conversely, it appears that with full adulthood, comes the establishment of stronger social ties, in comparison with adolescence.

Table 6.2. Percentage of respondents who have non-familial friends to turn to in emergency or with problems, by age group

\begin{tabular}{ccccc}
$\begin{array}{c}10 \text { to } 19 \\
(n=1049)\end{array}$ & $\begin{array}{c}20 \text { to } 29 \\
(n=1220)\end{array}$ & $\begin{array}{c}30 \text { to } 39 \\
(n=652)\end{array}$ & $\begin{array}{c}40 \text { to } 45 \\
(n=301)\end{array}$ & $\begin{array}{c}\text { All } \\
(n=3222)\end{array}$ \\
$28.4^{* * *}$ & 53.8 & 50.6 & 50.2 & 44.6 \\
$28.6^{* * *}$ & 49.4 & 49.9 & 47.5 & 42.5 \\
$32.1^{* * *}$ & 44.3 & 42.9 & 43.2 & 39.9 \\
$23.3^{* * *}$ & 41.2 & 43.0 & 39.5 & 35.6 \\
$27.9^{* * *}$ & 38.7 & 37.6 & 36.9 & 34.8 \\
\hline
\end{tabular}

There is someone to ask advice in the event of marriage or family problems

There is someone from whom to borrow food

Has a place to stay if there is a family problem

There is someone from whom can borrow money in an emergency

There is someone to confide in in case respondent is raped

$23.3^{* * *}$
$27.9^{* * *}$

38.7

35.6

${ }^{* * \star}$ Differences between groups significant at $p<0.001$

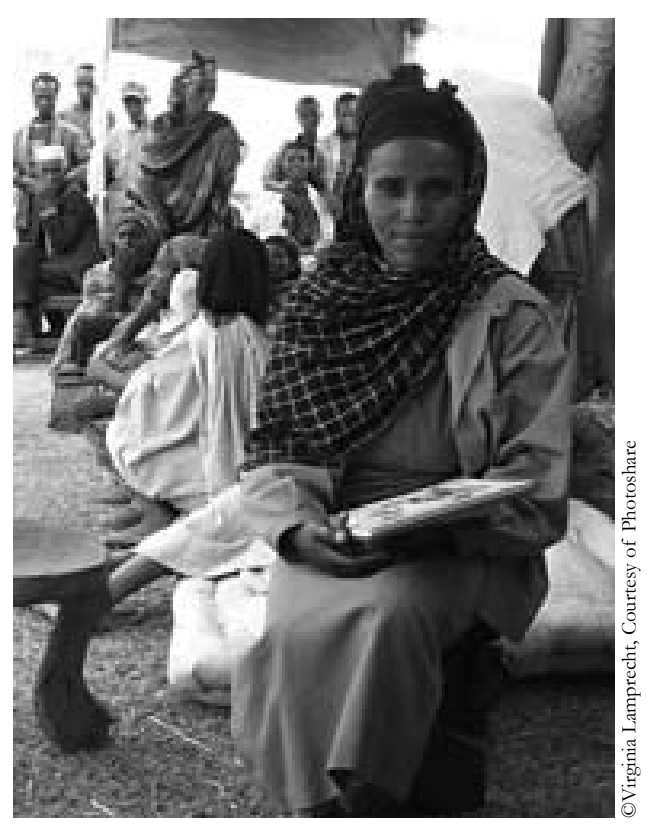




\section{Marriage \& Sexual Activity}

\section{Attitudes toward marriage}

Respondents viewed the ideal marriage age for a girl as quite young, 16 years on average compared to 20 for boys. Nearly one in five respondents (19 percent) viewed the best age for girls to get married at an age before 15, compared to only 3 percent of respondents who held this view for males. Conversely, while only 4 percent of respondents named an ideal marriage age for girls as age 20 or older, fully 71 percent of respondents felt an older marriage age was ideal for boys. Views on age at marriage differed by age group, marital status and education. Never married respondents and those who had been to school had the most progressive views on marriage age with over 75 percent feeling that a girl's ideal marriage age was at least age 18 .

Table 7.1: Ideal age at marriage for males and females, by age group, marital status and education

\begin{tabular}{|c|c|c|c|c|c|c|c|c|}
\hline & $\begin{array}{l}10 \text { to } 19 \\
\text { (n=1012) }\end{array}$ & $\begin{array}{l}20 \text { to } 29 \\
\text { (n=1184) }\end{array}$ & $\begin{array}{c}30 \text { to } 45 \\
(\mathrm{n}=926\end{array}$ & $\begin{array}{c}\text { Never married } \\
\quad(n=758)\end{array}$ & $\begin{array}{c}\text { Married } \\
(n=2363)\end{array}$ & $\begin{array}{l}\text { No educ } \\
(\mathrm{n}=2253)\end{array}$ & $\begin{array}{c}\text { Some educ } \\
(\mathrm{n}=867)\end{array}$ & $\begin{array}{c}\text { All } \\
(n=3222)\end{array}$ \\
\hline \multicolumn{9}{|c|}{ Ideal female marriage age } \\
\hline Below age 15 & 11.6 & 22.0 & 21.6 & 6.7 & 22.3 & 23.3 & 6.0 & 18.5 \\
\hline Age 15 to 17 & 21.0 & 30.2 & 29.5 & 16.9 & 30.3 & 32.3 & 13.1 & 27.0 \\
\hline Age 18 to 19 & 62.5 & 44.3 & 44.3 & 71.1 & 43.5 & 40.6 & 75.1 & 50.2 \\
\hline Age 20+ & 4.8 & 3.5 & 4.6 & 5.3 & 4.0 & 3.7 & 5.8 & 4.3 \\
\hline \multicolumn{9}{|c|}{ Ideal male marriage age } \\
\hline Below age 15 & 2.2 & 4.2 & 3.4 & 1.6 & 3.9 & 4.1 & 1.3 & 3.3 \\
\hline Age 15 to 17 & 10.2 & 13.1 & 12.2 & 6.8 & 13.5 & 14.3 & 5.7 & 11.9 \\
\hline Age 18 to 19 & 14.1 & 13.3 & 12.9 & 13.0 & 13.6 & 14.2 & 11.2 & 13.4 \\
\hline Age $20+$ & 73.6 & 69.4 & 71.5 & 78.6 & 69.1 & 67.4 & 81.8 & 71.4 \\
\hline
\end{tabular}

The practice of arranged marriage was approved of by the majority of respondents. Three quarters of respondents (75 percent) supported the practice of arranged marriage, with views varying by age, educational level and marital status. Younger, more educated and unmarried girls and women were less likely to believe that arranged marriage was advisable, compared to older, uneducated, married women. For example, 84 percent of respondents with no education approved of arranged marriage compared to only 51 percent of respondents who had been to school; 82 percent of ever-married respondents approved of arrangement compared to 53 percent of unmarried women.

\section{Age at marriage}

Median age at first marriage was quite low, especially for women in the oldest age cohort and those who never went to school. Median age at first marriage was 17.3 among those aged 10 to 19, 14.1 among those aged 20 
to 29, and 13.3 among those aged 30 and over. Those who had attended school seem to marry the latest with median age at first being 17.9 for women who had attended school (Figure 1).

Figure 1: Cumulative proportioin of respondents married by age and education

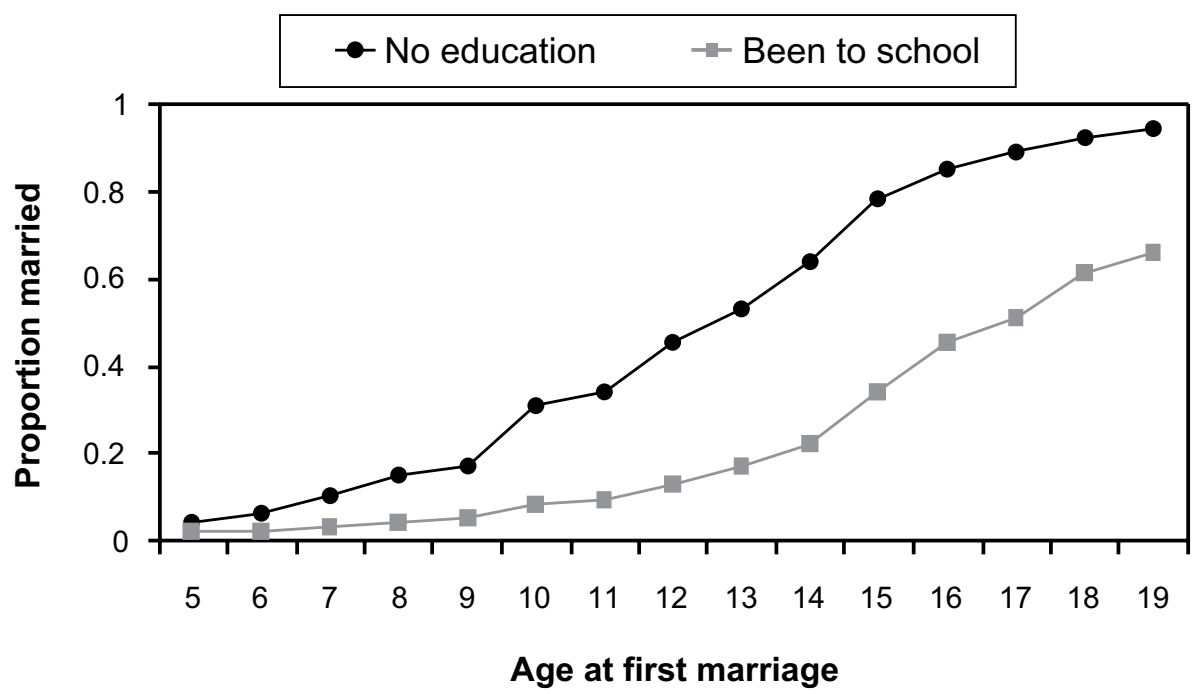

Average age difference with the first spouse was $7^{1} / 2$ years, which is consistent with other studies of marriage in Ethiopia. ${ }^{4}$ Contrary to studies in other settings, age difference with the spouse did not decrease when marriage age increased. Regardless of the age at which respondents were married, on average, their spouses were roughly $7^{1} /{ }_{2}$ years older than them.

Twenty eight percent of respondents are in polygamous unions. Polygamy is not as common in these highland communities as other regions of Ethiopia. At the same time, there was some indication of extra-marital unions among husbands of respondents (15 percent) and respondents themselves (6 percent) (see Table 7.3).

\section{Consent to marry}

The vast majority of marriages were arranged and were not consented to by the bride. Overall, 94 percent of marriages were arranged by parents. That similar percentages of marriages are arranged across age cohorts suggests that the practice of arranged marriage is not changing in the region. In only 16 percent of first marriages was consent given by the bride. The extent to which marriages are consented to is associated with the age at marriage. Only 4 percent of girls who marry below age 10 consented to the married; 12 percent who married between ages 10 to 14

${ }^{4}$ National Committee on Traditional Practices of Ethiopia (NCTPE). 2003. Old beyond imaginings: Ethiopia harmful traditional practices, Addis Ababa: NCTPE and NORAD. 
consented, while 29 percent of those who married from 15 to 19 gave consent. Regardless of age at marriage, only a minority of marriages in the study sites were consented to by brides.

Table 7.2: Percentage of marriages that were arranged and with consent given, by age at marriage and age category.

\begin{tabular}{|c|c|c|c|c|c|c|c|c|}
\hline & \multicolumn{4}{|c|}{ Age at marriage } & \multicolumn{3}{|c|}{ Age group } & \multirow[b]{2}{*}{$\begin{array}{c}\text { All } \\
(n=2444)\end{array}$} \\
\hline & $\begin{array}{c}<10 \\
(n=429)\end{array}$ & $\begin{array}{l}10 \text { to } 14 \\
(n=1182)\end{array}$ & $\begin{array}{l}15 \text { to } 19 \\
(n=728)\end{array}$ & $\begin{array}{c}20+ \\
(n=81)\end{array}$ & $\begin{array}{l}10 \text { to } 19 \\
(n=327)\end{array}$ & $\begin{array}{l}20 \text { to } 29 \\
(n=1159)\end{array}$ & $\begin{array}{l}30 \text { to } 39 \\
(n=935)\end{array}$ & \\
\hline Arranged by parents & 98.1 & 95.1 & 91.1 & 84.0 & 95.1 & 94.5 & 93.2 & 94.1 \\
\hline \multicolumn{9}{|l|}{ Consent given } \\
\hline No & 96.5 & 88.3 & 70.9 & 59.3 & 82.2 & 83.7 & 83.6 & 83.6 \\
\hline Yes & 3.5 & 11.7 & 29.1 & 40.7 & 17.8 & 16.3 & 16.4 & 16.4 \\
\hline
\end{tabular}

\section{Experience of marriage}

When asked about the timing of their marriage, 59 percent of respondents felt that they were married too early, 4 percent felt their marriage occurred too late, and 35 percent felt the timing was about right. Opinions on the timing of marriage varied by age at marriage. Girls who married at young ages felt their marriage occurred too early, with 93 percent of girls married before age 10 and 70 percent who married between the ages of 10 to 14 , feeling they married too early.

\section{I was married and sent to a far area. I hated my life because I see my [own] family only once a year. My friends were sent to places not very far from their families. (Age 25, no education, married at age 15 to 26 year old man, first sex age 15, first birth age 16, 3 cbildren)}

Ever-married respondents were read statements related to their relationship with their husband and asked if they agreed or disagreed ${ }^{5}$ (Table 7.3). Fully 15 percent of married women feel their husband has not always been faithful and 8 percent suspect them of frequenting sex workers. About one in ten married women have experienced violence in the past year with 11 percent reporting being hit in the last year and 12 percent reporting sex that was forced by their husband.

\section{Divorce and remarriage}

Divorce and remarriage is very common among respondents. Twentysix percent of first marriages ended in divorce. Many divorced women get remarried with 20 percent of the sample having been married twice

${ }^{5}$ It should be noted that many of the issues raised in Table 7.3 are sensitive and some misreporting, especially underreporting may have taken place.

I was married and sent to a far area. I hated my life because I see my [own] family only once a year. My friends were sent to places not very far from their families.

- Age 25, no education, married at age 15 to 26 year old man, first sex age 15 , first birth age 16,3 children 
Table 7.3: Respondents' relationship to current or most recent spouse ( $n=2444)$ (percentage agreeing with statements)

\begin{tabular}{lc}
\hline Relationship to spouse & Percentage \\
\hline Your husband respects your opinions and ideas & 84.7 \\
You depend on your spouse financially & 72.2 \\
You are able to refuse your husband sex & 22.5 \\
You would like to leave/divorce husband, but cannot & 12.2 \\
Faithfulness & \\
You think your husband has not always been faithful & 15.3 \\
You have not always been faithful to husband & 6.3 \\
You suspect your husband goes with sex workers & 7.6 \\
You feel scared your husband will infect you with HIV & 5.5 \\
Violence & \\
You have been hit by your spouse in the last year & 10.7 \\
You have been forced to have sex by your spouse in the last year & 11.5 \\
\hline
\end{tabular}

and 8 percent having been married three or more times. Early marriage is associated with high rates of divorce, a finding that is consistent with other studies of marriage in Ethiopia. ${ }^{6}$ Among girls who married before the age of 10, 47 percent were married more than once. In comparison, 33 percent of girls who married from age 10 to 14 married more than once and only 12 percent of young women who married after age 20 were divorced and remarried.

\section{Sexual activity}

Ninety-nine percent of respondents first had sex with their husband, reflecting that sexual initiation takes place in the context of marriage. Indeed the timing of first sex was associated with age at first marriage. Though not all respondents who were married had sex immediately, the earlier that one married, the earlier that one had sex. Among those married at age 10 or less, median age at first sex was 12.7 years; among those marriage during early adolescence (10 to 14) median age at first sex was 13.3; for girls married from age 15 to 19 , median age at first sex was 16.0.

The earlier that sexual initiation took place, the less likely that it was wanted. The vast majority of girls who had first sex before age 15 did not want it (Table 7.4).

${ }^{6}$ Tilson D and Larsen U. 2000. Divorce in Ethiopia: The impact of early marriage and childlessness. Journal of Biosocial Science, 32(3), 355-372. 
Table 7.4: 'Wantedness' of first sex, by age at first sex

\begin{tabular}{lccc}
\hline Age at first sex & Wanted sex & Did not want sex & Was undecided \\
\hline Less than 10 $(n=35)$ & 8.6 & 74.3 & 17.1 \\
Age 10 to 14 $(n=1307)$ & 14.6 & 69.5 & 15.8 \\
Age 15 to 19 $(n=1002)$ & 31.7 & 54.3 & 14.0 \\
Age 20 $+(n=85)$ & 54.1 & 35.3 & 10.6 \\
\hline
\end{tabular}

\section{Attitudes Toward Health Issues}

Respondents were read a list of health issues and asked if they considered each issue to be a "big problem," "somewhat of a problem," or "no problem at all" in their communities (Table 8.1). Malaria was considered a big health problem by the vast majority of respondents (94 percent). After malaria, tuberculosis and HIV/AIDS were considered "big problems" by 22 and 14 percent of respondents, respectively. Few respondents considered maternal death, other sexually transmitted infections or fistula as pressing concerns.

Ninety two percent of respondents know of the clinic or health center in their area, and 77 percent have ever been to a health facility. Among those who have been to the clinic in the past year, malaria was the main reason for going (77 percent), followed by antenatal care (10 percent), coughs and colds ( 4 percent), and tuberculosis (3 percent).

Table 8.1: Percentage of respondents considering health issues a "big problem" in their community $(n=3222)$

\begin{tabular}{lc}
\hline Health issue & Percentage \\
\hline Malaria & 93.5 \\
Tuberculosis & 22.0 \\
HIV/AIDS & 14.1 \\
Diarrhea & 7.2 \\
Malnutrition & 4.5 \\
Maternal death/mortality & 2.5 \\
Sexually transmitted infections (other than HIVIAIDS) & 0.7 \\
Fistula & 0.2 \\
\hline
\end{tabular}




\section{Family Planning}

\section{Awareness of family planning}

The majority of respondents were aware of family planning (FP) methods such as pills, depo, and condoms (Table 9.1). Knowledge of other modern methods was extremely low, especially related to IUCD, foaming tablets and emergency contraception. On average, respondents were aware of three FP methods out of the nine mentioned. Respondents with some education were more likely to be aware of methods than others.

Table 9.1: Knowledge of family planning methods, by age group and educational status

\begin{tabular}{|c|c|c|c|c|c|c|}
\hline Method & $\begin{array}{c}10-19 \\
(n=1049)\end{array}$ & $\begin{array}{c}20-29 \\
(n=1220)\end{array}$ & $\begin{array}{c}30-45 \\
(n=953)\end{array}$ & $\begin{array}{l}\text { No educ. } \\
(n=2337)\end{array}$ & $\begin{array}{c}\text { Some educ. } \\
\qquad(n=883)\end{array}$ & $\begin{array}{c}\text { All } \\
(n=3222)\end{array}$ \\
\hline Pills & 95.8 & 97.5 & 97.1 & 96.5 & 97.6 & 96.8 \\
\hline Injectables/Depo & 95.5 & 97.1 & 96.8 & 96.2 & 97.4 & 96.5 \\
\hline Condom & 78.6 & 76.0 & 72.3 & 71.8 & 86.2 & 75.7 \\
\hline Norplant & 18.5 & 13.7 & 13.7 & 10.2 & 28.7 & 15.3 \\
\hline IUD & 10.8 & 6.2 & 4.6 & 3.7 & 16.5 & 7.2 \\
\hline Foaming Tablets & 3.7 & 2.4 & 2.5 & 1.8 & 5.6 & 2.9 \\
\hline Emergency Contraception & 2.2 & 0.8 & 0.5 & 0.2 & 3.9 & 1.2 \\
\hline Safe days & 5.6 & 3.2 & 2.2 & 1.6 & 9.2 & 3.7 \\
\hline Withdrawal & 2.9 & 1.0 & 0.4 & 0.1 & 4.9 & 1.4 \\
\hline Mean no. of methods known & 3.2 & 3.0 & 2.9 & 2.8 & 3.5 & 3.0 \\
\hline
\end{tabular}

\section{Family planning use}

Use of FP methods was extremely low. Only 13 percent of sexually active respondents were using a method, with most (11 percent) using injectables and the remainder using pills. Among non-users of FP, only 16 percent know where to get a FP method in their area, which could contribute to the high levels of non-use among respondents.

Table 9.2: Ever and current use of family planning among sexually active respondents $(n=2434)$

\begin{tabular}{lcc}
\hline Method & Ever use & Current use \\
\hline Pills & 9.8 & 1.4 \\
Depo & 22.0 & 11.4 \\
Condom & 0.2 & 0.0 \\
Norplant & 0.2 & 0.0 \\
IUD & 0.0 & 0.0 \\
Foaming Tablets & 0.0 & 0.0 \\
Emergency Contraception & 0.0 & 0.0 \\
Safe days & 0.6 & 0.0 \\
Withdrawal & 0.0 & 0.0 \\
\hline
\end{tabular}




\section{Community and individual attitudes about fertility and family planning}

Respondents held a number of attitudes that undoubtedly contributed to the low use of FP (Table 9.3). A large percentage of respondents felt that women should have additional children in case some died during infancy (81 percent) and so that they are cared for during old age (79 percent). Similarly, a large proportion of women felt that the number of children one has is "up to God" (65 percent). These attitudes differed significantly by the education of the respondent, with unschooled women significantly more likely to hold these attitudes compared to women who had been to school.

One significant barrier to FP use appeared to be husbands, with nearly one third of women (32 percent) reporting that their husbands do not approve of FP. In comparison, fewer respondents reported that FP was too expensive (18 percent) or unsafe (19 percent), or that they did not see the benefit (15 percent).

Table 9.3: Percentage of respondents agreeing with statements related to desired family size and family planning, by level of education and age group

\begin{tabular}{|c|c|c|c|c|c|c|}
\hline \multirow[b]{2}{*}{ Percentage agreeing } & \multicolumn{2}{|c|}{ Level of education } & \multicolumn{3}{|c|}{ Age group } & \multirow[b]{2}{*}{$\underset{\substack{\text { All } \\
(n=3223)}}{-}$} \\
\hline & $\begin{array}{l}\text { No educ } \\
(\mathrm{n}=2338)\end{array}$ & $\begin{array}{l}\text { Some educ } \\
(n=883)\end{array}$ & $\begin{array}{l}10 \text { to } 19 \\
(n=1049)\end{array}$ & $\begin{array}{l}20 \text { to } 29 \\
(n=1220)\end{array}$ & $\begin{array}{l}30 \text { to } 45 \\
(n=954)\end{array}$ & \\
\hline $\begin{array}{l}\text { Women should have extra children in case } \\
\text { some die in infancy or childhood }\end{array}$ & 84.9 & 71.7 & 74.7 & 84.2 & 84.9 & 81.3 \\
\hline $\begin{array}{l}\text { Women should have enough children so } \\
\text { they are taken care of in old age }\end{array}$ & 84.0 & 67.0 & 72.9 & 81.1 & 84.3 & 79.4 \\
\hline $\begin{array}{l}\text { The number of children a woman has is up } \\
\text { to God }\end{array}$ & 71.6 & 46.3 & 53.3 & 68.4 & 72.4 & 64.7 \\
\hline $\begin{array}{l}\text { Your husband does not approve of family } \\
\text { planning methods* }\end{array}$ & 32.8 & 22.5 & 27.6 & 29.3 & 36.4 & 31.7 \\
\hline Family planning methods are unsafe to use & 22.8 & 10.1 & 13.7 & 19.0 & 25.7 & 19.3 \\
\hline $\begin{array}{l}\text { Family planning would be too expensive for } \\
\text { you to use }\end{array}$ & 17.8 & 18.4 & 18.1 & 19.4 & 15.8 & 17.9 \\
\hline You don't see the benefit of family planning & 17.9 & 7.7 & 11.2 & 14.9 & 19.5 & 15.1 \\
\hline $\begin{array}{l}\text { Family planning is more for people in towns, } \\
\text { not the rural area }\end{array}$ & 12.8 & 5.8 & 8.6 & 10.8 & 13.5 & 10.9 \\
\hline
\end{tabular}

${ }^{*}$ Among ever-married women 


\section{HIV/AIDS}

\section{Knowledge of HIV/AIDS}

Respondents were highly knowledgeable on relatively basic information related to HIV/AIDS such as that a healthy looking person can still be infected (88 percent) or that there is no cure for HIV/AIDS (86 percent). However a surprisingly large proportion of respondents did not know about the protective benefits of condoms (54 percent). Similarly, an alarming proportion of respondents (41 percent) did not know that HIV is not only transmitted in towns.

Table 10.1: Knowledge about HIV/AIDS, by level of education and age group

\begin{tabular}{|c|c|c|c|c|c|c|}
\hline & \multicolumn{2}{|c|}{ Level of education } & \multicolumn{4}{|c|}{ Age group } \\
\hline & $\begin{array}{l}\text { No educ } \\
(\mathrm{n}=2338)\end{array}$ & $\begin{array}{c}\text { Some educ } \\
(n=883)\end{array}$ & $\begin{array}{l}10 \text { to } 19 \\
(n=1049)\end{array}$ & $\begin{array}{l}20 \text { to } 29 \\
(n=1220)\end{array}$ & $\begin{array}{l}30 \text { to } 45 \\
(n=954)\end{array}$ & $\begin{array}{c}\text { All } \\
(n=3223)\end{array}$ \\
\hline $\begin{array}{l}\text { Know that a healthy-looking person can still have } \\
\text { HIV }\end{array}$ & 86.6 & 90.4 & 88.6 & 87.7 & 86.5 & 87.6 \\
\hline Know that there is no cure for HIVIAIDS & 85.1 & 88.8 & 88.5 & 85.7 & 83.9 & 86.1 \\
\hline $\begin{array}{l}\text { Know that an HIV + pregnant woman can give it to } \\
\text { her unborn child }\end{array}$ & 78.6 & 86.7 & 81.8 & 81.6 & 79.0 & 80.9 \\
\hline $\begin{array}{l}\text { Know that one cannot get HIV from sharing eating } \\
\text { utensils }\end{array}$ & 65.7 & 59.3 & 61.0 & 64.2 & 66.9 & 64.0 \\
\hline Know that HIV is not only contracted in towns & 54.4 & 72.3 & 65.0 & 56.5 & 56.7 & 59.3 \\
\hline $\begin{array}{l}\text { Know that condoms are effective in preventing HIV } \\
\text { transmission }\end{array}$ & 38.3 & 67.6 & 57.7 & 43.2 & 37.9 & 46.3 \\
\hline
\end{tabular}

\section{Personal experience with HIV/AIDS}

Nineteen percent of respondents reported they knew someone who was sick with or had died of AIDS. Most people named an acquaintance or neighbor as the person they knew. Only 2 percent reported that a family member had been sick with HIV/AIDS.

Few respondents consider themselves personally at risk of HIV/AIDS. Only 4 percent reported they worry that they may be HIV+. When asked about personal risk, 92 percent considered themselves at "no risk," 6 percent at "small risk," and only 2 percent at "great risk."

Though respondents considered their personal risk small, there was high demand for VCT. Fully 45 percent reported that they would like to be tested for HIV, with educated respondents and those in the younger age groups significantly more likely to want to be tested.

\section{Community and individual attitudes about HIV/AIDS}

A majority of respondents felt that knowing their HIV status would help protect their families (84 percent). At the same time, a considerable 
proportion, 54 percent, did not want to know their status for fear of rejection from the community. Fear of community rejection appeared to be a powerful deterrent. Fifty percent of those feeling that knowing one's status was a positive step, also said they would not like to know their status for fear of rejection. One fifth of respondents feared that their husband would leave them or blame them if they were HIV positive (Table 10.2).

Table 10.2: Percentage of respondents agreeing with statements related to HIVIAIDS, by level of education and age group

\begin{tabular}{|c|c|c|c|c|c|c|}
\hline \multirow[b]{2}{*}{ Percentage agreeing } & \multicolumn{2}{|c|}{ Level of education } & \multicolumn{3}{|c|}{ Age group } & \multirow[b]{2}{*}{$\begin{array}{c}\text { All } \\
(n=3223)\end{array}$} \\
\hline & $\begin{array}{l}\text { No educ } \\
(n=2338)\end{array}$ & $\begin{array}{l}\text { Some educ } \\
(n=883)\end{array}$ & $\begin{array}{l}10 \text { to } 19 \\
(n=1049)\end{array}$ & $\begin{array}{l}20 \text { to } 29 \\
(n=1220)\end{array}$ & $\begin{array}{l}30 \text { to } 45 \\
(n=954)\end{array}$ & \\
\hline $\begin{array}{l}\text { Knowing your HIV status will help you protect your } \\
\text { family }\end{array}$ & 82.3 & 88.9 & 87.0 & 84.0 & 81.1 & 84.1 \\
\hline $\begin{array}{l}\text { You do not want to know your HIV status because } \\
\text { the community would reject you if you were positive }\end{array}$ & 57.0 & 46.8 & 50.6 & 55.2 & 56.9 & 54.2 \\
\hline $\begin{array}{l}\text { There is no point in your knowing your HIV status } \\
\text { because there is nothing you can do }\end{array}$ & 33.1 & 20.0 & 22.9 & 30.5 & 35.6 & 29.5 \\
\hline If you were HIV +, your husband would blame you* & 20.8 & 20.6 & 21.1 & 19.4 & 22.5 & 20.8 \\
\hline If you were HIV+, your husband would leave you* & 18.6 & 18.0 & 18.8 & 17.8 & 20.0 & 18.0 \\
\hline
\end{tabular}

${ }^{*}$ Among ever-married women

Indeed, the fear of community rejection appeared valid as many respondents themselves appeared to stigmatize those with HIV (Table 10.3). The majority (nearly 80 percent) would not be willing to share food with or care for a person living with AIDS. About one quarter of respondents felt that an HIV+ teacher should not be allowed to continue teaching and that an HIV + student should not attend school with healthy children. Those with some education and younger respondents were far less likely to stigmatize those living with AIDS than were older or less educated respondents.

Table 10.3: Percentage of respondents holding negative views of HIV infected people, by level of education and age group

\begin{tabular}{|c|c|c|c|c|c|c|}
\hline \multirow[b]{2}{*}{ Percentage agreeing } & \multicolumn{2}{|c|}{ Level of education } & \multicolumn{3}{|c|}{ Age group } & \multirow[b]{2}{*}{$\begin{array}{c}\text { All } \\
(n=3223)\end{array}$} \\
\hline & $\begin{array}{l}\text { No educ } \\
(n=2338)\end{array}$ & $\begin{array}{c}\text { Some educ } \\
(n=883)\end{array}$ & $\begin{array}{l}10 \text { to } 19 \\
(n=1049)\end{array}$ & $\begin{array}{l}20 \text { to } 29 \\
(n=1220)\end{array}$ & $\begin{array}{l}30 \text { to } 45 \\
(n=954)\end{array}$ & \\
\hline $\begin{array}{l}\text { You would not be willing to share food with a person } \\
\text { with AIDS }\end{array}$ & 87.8 & 57.8 & 68.4 & 84.5 & 85.4 & 79.5 \\
\hline $\begin{array}{l}\text { You would not be willing to care for a person with } \\
\text { AIDS }\end{array}$ & 86.8 & 54.8 & 67.2 & 82.8 & 84.0 & 78.1 \\
\hline $\begin{array}{l}\text { An HIV+ teacher should not be allowed to continue } \\
\text { teaching }\end{array}$ & 31.6 & 15.9 & 23.5 & 28.9 & 29.5 & 27.3 \\
\hline $\begin{array}{l}\text { A child who is HIV positive should not be allowed to } \\
\text { go to school with healthy children }\end{array}$ & 30.0 & 17.6 & 23.1 & 26.9 & 29.9 & 26.5 \\
\hline
\end{tabular}




\section{Xi. Maternal \& Child Health}

\section{Timing and 'wantedness' of first birth}

Overall, 65 percent of the sample have given birth (Table 11.1). A considerable proportion of respondents gave birth during early adolescence with 17 percent of the sample having given birth by age 15. There appears to be a delay in first birth through successive cohorts of women. Among girls aged 10 to 19,48 percent have given birth by age 18, compared to 63 percent of those aged 20 to 29 and 71 percent of women aged 30 to 45. Women in the oldest age group (30 to 45) have an average of 4.8 children. At the same time, desired family size is relatively high, with an average desired family size of five children. Younger respondents report wanting smaller families with those aged 10 to 19 wanting an average of 4 children.

Nearly all first births were within the context of marriage; less than one percent of respondents reported a first birth with someone other than a spouse. This implies that the timing of marriage closely related to the timing of first birth, with virtually no unmarried women having children. Premarital sex and out-of-wedlock pregnancy is often a concern addressed by youth programs. This data suggests that premarital sex is quite uncommon in this rural population and that early teen pregnancies are, in fact, linked to early teen or child marriages, not to premarital sex.

Table 11.1 Percentage of respondents who have given birth, relationship to father of child and desired number of children, by age group

\begin{tabular}{|c|c|c|c|c|}
\hline & $\begin{array}{l}10 \text { to } 19 \\
(n=1049)\end{array}$ & $\begin{array}{l}20 \text { to } 29 \\
(n=1220)\end{array}$ & $\begin{array}{l}30 \text { to } 45 \\
(n=954)\end{array}$ & $\begin{array}{c}\text { All } \\
(n=3223)\end{array}$ \\
\hline Have given birth & 15.2 & 85.8 & 95.7 & 65.4 \\
\hline Gave birth by age 15 & 8.0 & 16.1 & 20.4 & 16.6 \\
\hline Gave birth by age 18 & 48.3 & 63.1 & 71.4 & 64.1 \\
\hline \multicolumn{5}{|l|}{ Relationship to the father of first child } \\
\hline Spouse & 98.1 & 99.0 & 99.3 & 99.1 \\
\hline Other & 1.9 & 1.0 & 0.7 & 0.7 \\
\hline Mean number of child (range) & $0.2(0-3)$ & $2.0(0-8)$ & $4.8(0-12)$ & $2.2(0-12)$ \\
\hline Desired number of children (range) & $3.8(0-10)$ & $4.4(0-13)$ & $5.6(0-14)$ & $4.9(0-14)$ \\
\hline
\end{tabular}

Many pregnancies are not desired at the time they occur. Figure 2 shows the percent of first births that are wanted at that time, by age at first birth. There is a clear relationship between age at first birth and the 'wantedness' of that birth, even when it occurs within the context of marriage. Only a minority of girls want a pregnancy when it occurs at an early age and even

${ }^{7}$ Calculation based on survival analysis which takes account of censored cases. 
Figure 2: Percentage of first births that are wanted, by age at first birth

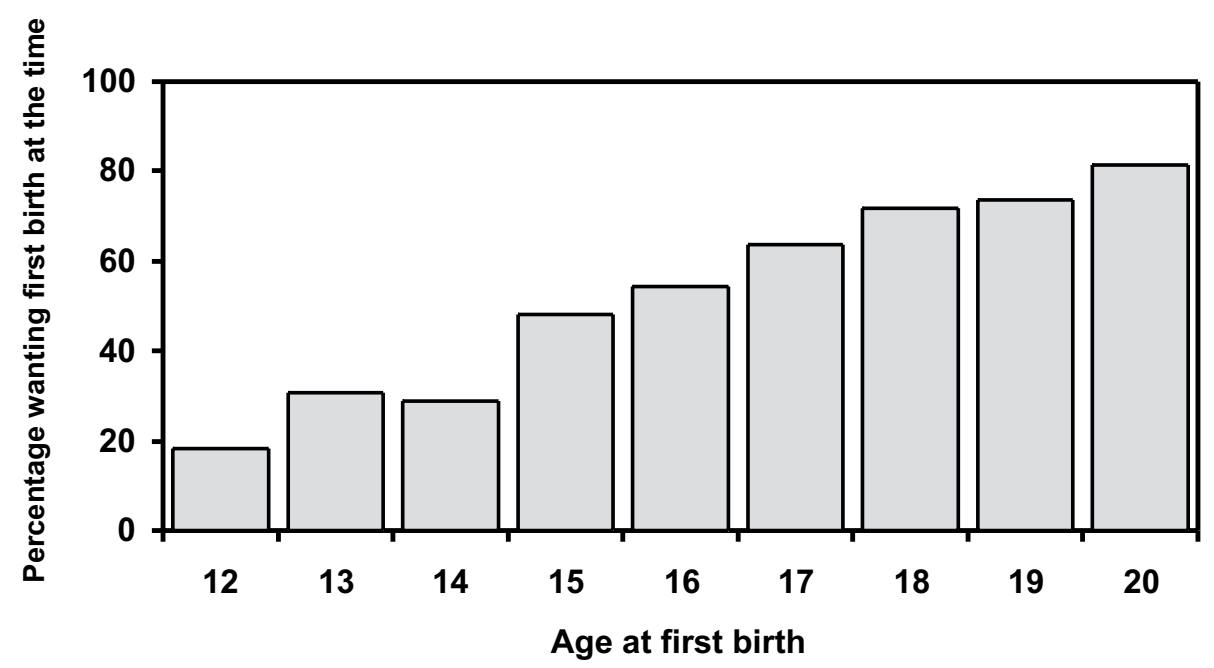

by age 20 , only 4 out of 5 respondents wanted to be pregnant at the time they were.

\section{Care during pregnancy and delivery}

About one in five women received antenatal care, with respondents who had been to school and those in the youngest age bracket being the most likely to receive care before delivery (45 percent and 39 percent, respectively). The most common place to deliver was at one's own mother's house, comprising 70 percent of respondents' first deliveries. Most deliveries were attended by unskilled attendants, with mothers being the most likely attendants (34 percent), followed by traditional birth attendants (TBA) (31 percent), and other relatives or friends (19 percent). The attendance of doctors or nurses was low (4 percent), but respondents were some education were much more likely to be attended by a doctor or nurse (13 percent), compared to other respondents. At the same time, the cost of being attended by a doctor or nurse was not insignificant. Those who were attended by a doctor/nurse paid, on average 60 Birr (US\$7) compared to 4 Birr (US\$0.50) paid to a TBA.

\section{Community and individual attitudes toward pregnancy and childbirth}

Respondents were read a list of statements regarding their own views and the views of the community toward childbirth (Table 11.3). Respondents perceive that their community, generally, as well as men in their community, and their own husbands prefer that childbirth take place in the home. In addition, many respondents consider that when a woman dies in childbirth, it is an act of God and there is nothing that could have been done to prevent it and that TBA's can handle almost any situation that arises in childbirth. Taken together, the community pressure and individual attitudes on home delivery likely support the continued practice in this region.
The first born is always delivered in the parent's house, the second and third are delivered in the husband's house. Since it was tradition, I decided that I should do the same. - Age 25, no education, married at age 10 to 22 year old man, first birth age 15, 4 children, first sex at age 14 
Table 11.2: Care and delivery during first pregnancy, by level of education and age group

\begin{tabular}{|c|c|c|c|c|c|c|}
\hline & \multicolumn{2}{|c|}{ Level of education } & \multicolumn{3}{|c|}{ Age group } & \multirow[b]{2}{*}{$\begin{array}{c}\text { All } \\
(n=2125)\end{array}$} \\
\hline & $\begin{array}{l}\text { No educ } \\
(n=1908)\end{array}$ & $\begin{array}{c}\text { Some educ } \\
(\mathrm{n}=217)\end{array}$ & $\begin{array}{l}10 \text { to } 19 \\
(n=161)\end{array}$ & $\begin{array}{l}20 \text { to } 29 \\
\text { ( } n=1049)\end{array}$ & $\begin{array}{l}30 \text { to } 45 \\
\text { ( } \mathrm{n}=917)\end{array}$ & \\
\hline Received antenatal care & 19.7 & 44.7 & 38.5 & 39.0 & 11.6 & 22.2 \\
\hline \multicolumn{7}{|l|}{ Location of delivery } \\
\hline Hospital / Clinic & 2.5 & 9.7 & 2.0 & 4.2 & 2.2 & 3.3 \\
\hline Spouse's house & 26.4 & 26.2 & 25.3 & 25.3 & 27.9 & 26.4 \\
\hline Mother's house & 71.1 & 64.1 & 72.7 & 70.5 & 69.9 & 70.3 \\
\hline \multicolumn{7}{|l|}{ Assistance during delivery } \\
\hline Doctor/Nurse & 3.1 & 12.6 & 6.3 & 4.9 & 2.8 & 4.1 \\
\hline Traditional birth attendant & 31.5 & 24.3 & 30.6 & 32.5 & 28.9 & 30.8 \\
\hline Mother & 34.7 & 31.8 & 30.2 & 32.4 & 37.2 & 34.3 \\
\hline Other relative/friend & 19.1 & 20.0 & 22.0 & 18.3 & 19.8 & 19.3 \\
\hline Other & 211.6 & 11.3 & 10.9 & 11.9 & 11.3 & 11.5 \\
\hline
\end{tabular}

The first born is always delivered in the parent's bouse, the second and third are delivered in the husband's house. Since it was tradition, I decided that I should do the same. (Age 25, no education, married at age 10 to 22 year old man, first birth age 15, 4 children, first sex at age 14)

Because it is our custom to deliver at your mother's house when you give birth to your first born. So I went to my mother's and delivered. Besides I prefer to have the baby at my mother's house because I know she will take good care of the baby and me. (Age 30, no education, married at age 8 to 20 year old, first birth at age 15, 6 children, first sex age 14)

We didn't even know there is such a thing as a health center, let alone the services it

gives.

- Age 35, no education, married at age 13 to 26 year old man, first birth at age 15,5 children, first sex at age 14
We didn't even know there is such a thing as a bealth center, let alone the services it gives. (Age 35, no education, married at age 13 to 26 year old man, first birth at age 15, 5 children, first sex at age 14)

Other barriers to clinical services seemed not to be as significant as community tradition. About one third felt that women generally lack time to go to the clinic and one fifth felt the clinic was too expensive. In addition, 20 percent of respondents had the perception that women are more likely to develop fistulas at the hospital than at home. 
Table 11.3: Percentage of respondents agreeing with statements related to safe motherhood, by level of education and age group

\begin{tabular}{|c|c|c|c|c|c|c|}
\hline \multirow[b]{2}{*}{ Percentage agreeing } & \multicolumn{2}{|c|}{ Level of education } & \multicolumn{3}{|c|}{ Age group } & \multirow[b]{2}{*}{$\underset{(n=3223)}{\text { All }}$} \\
\hline & $\begin{array}{l}\text { No educ } \\
(\mathrm{n}=2338)\end{array}$ & $\begin{array}{c}\text { Some educ } \\
(\mathrm{n}=883)\end{array}$ & $\begin{array}{l}10 \text { to } 19 \\
(n=1049)\end{array}$ & $\begin{array}{l}20 \text { to } 29 \\
(n=1220)\end{array}$ & $\begin{array}{l}30 \text { to } 45 \\
(n=954)\end{array}$ & \\
\hline $\begin{array}{l}\text { It is tradition in this community for women to deliver } \\
\text { at home }\end{array}$ & 92.1 & 86.2 & 87.7 & 92.3 & 91.5 & 90.5 \\
\hline $\begin{array}{l}\text { In your community, most men prefer women to } \\
\text { deliver at home }\end{array}$ & 89.4 & 83.8 & 86.4 & 88.6 & 88.6 & 87.9 \\
\hline Your husband prefers that you deliver at home* & 81.5 & 68.7 & 82.2 & 80.5 & 78.8 & 80.1 \\
\hline $\begin{array}{l}\text { It is better for a healthy woman to deliver at home } \\
\text { than at a clinic }\end{array}$ & 82.2 & 53.2 & 62.7 & 80.1 & 79.5 & 74.2 \\
\hline $\begin{array}{l}\text { When a woman dies during childbirth, it is an act of } \\
\text { God and there is nothing that could have been done }\end{array}$ & 77.1 & 56.4 & 62.3 & 74.3 & 77.6 & 71.4 \\
\hline $\begin{array}{l}\text { A traditional birth attendant can handle most } \\
\text { problems that women experience during childbirth }\end{array}$ & 72.4 & 58.8 & 61.8 & 70.5 & 74.0 & 68.7 \\
\hline $\begin{array}{l}\text { A healthy woman does not need to see a medical } \\
\text { professional during her pregnancy }\end{array}$ & 52.7 & 27.1 & 35.0 & 49.5 & 50.9 & 45.2 \\
\hline $\begin{array}{l}\text { Most women do not have time to visit the clinic } \\
\text { during pregnancy }\end{array}$ & 38.0 & 33.2 & 35.2 & 35.7 & 39.5 & 36.7 \\
\hline It is too expensive to go to a clinic during pregnancy & 24.7 & 14.9 & 18.2 & 23.0 & 24.9 & 22.0 \\
\hline $\begin{array}{l}\text { Women should not give birth at the clinic because } \\
\text { they often develop fistulas there }\end{array}$ & 24.3 & 11.1 & 16.4 & 23.1 & 22.3 & 20.7 \\
\hline
\end{tabular}

*Among ever-married women

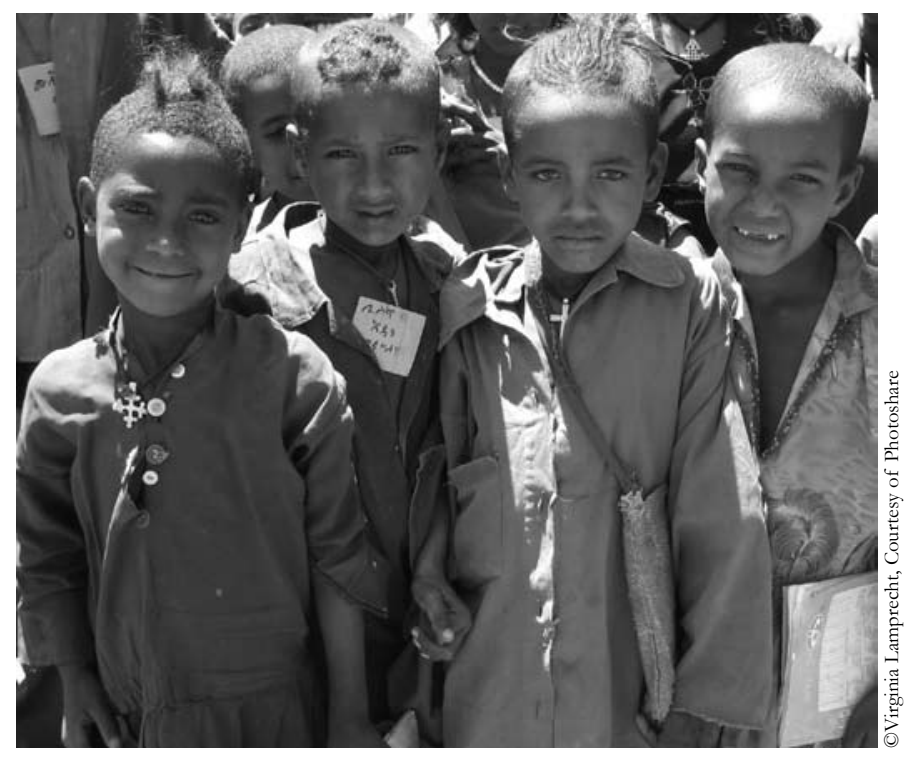


About one third of respondents reported that they would circumcise daughters because it is normal in their community and 28 percent felt their families would criticize them if they

did not circumcise their daughters.

\section{Female Genital Cutting}

Over 80 percent of respondents have been circumcised. Educated respondents and those in the youngest age bracket were somewhat less likely to be circumcised, with 67 percent of educated respondents and 70 percent of respondents aged 10 to 19 having been circumcised. At the same time, among respondents with daughters, far fewer reported having circumcised their daughter, 47 percent, with the lowest percentages of circumcision among the youngest mothers. Among mothers who circumcised their daughters, 86 percent reported that it was done during infancy; 88 percent of circumcisions were done by traditional circumcisers and 8 percent were done by TBAs.

Table 12.1: Prevalence of and attitudes toward female genital cutting, by educational level and age group

\begin{tabular}{|c|c|c|c|c|c|c|}
\hline & \multicolumn{2}{|c|}{ Level of education } & \multicolumn{3}{|c|}{ Age group } & \multirow[b]{2}{*}{$\begin{array}{c}\text { All } \\
(n=3223)\end{array}$} \\
\hline & $\begin{array}{l}\text { No educ } \\
(\mathrm{n}=2338)\end{array}$ & $\begin{array}{c}\text { Some educ } \\
(n=883)\end{array}$ & $\begin{array}{l}10 \text { to } 19 \\
(n=1049)\end{array}$ & $\begin{array}{l}20 \text { to } 29 \\
(n=1220)\end{array}$ & $\begin{array}{l}30 \text { to } 45 \\
(n=954)\end{array}$ & \\
\hline Circumcised & 86.7 & 67.1 & 70.3 & 85.5 & 88.1 & 81.4 \\
\hline $\begin{array}{l}\text { Circumcised daughter } \\
\text { (among respondents with daughters) }\end{array}$ & 49.8 & 31.7 & 10.0 & 40.2 & 57.6 & 47.2 \\
\hline Attitudes (percent agreeing) & & & & & & \\
\hline $\begin{array}{l}\text { You would circumcise your daughter because } \\
\text { it is normal in your community }\end{array}$ & 36.8 & 12.3 & 19.4 & 33.8 & 37.3 & 30.1 \\
\hline $\begin{array}{l}\text { If you didn't circumcise your daughter, your } \\
\text { family would criticize you }\end{array}$ & 32.0 & 18.4 & 21.8 & 31.4 & 31.4 & 28.3 \\
\hline
\end{tabular}

About one third of respondents reported that they would circumcise daughters because it is normal in their community and 28 percent felt their families would criticize them if they did not circumcise their daughters. In fact, fear of family criticism may have played a part in the circumcision of some of the respondents' daughters. Among those who circumcised their children, 70 percent reported that their families would criticize them if she had not have been circumcised.

\section{Exposure to Reproductive Health Messages}

A substantial proportion of respondents (64 percent) had heard an educational message related to $\mathrm{RH}$ in the last year. The most common media were lectures (47 percent), through health providers (39 percent), and over the radio (31 percent). Given low rates of literacy, it is not surprising that few respondents were reached by newspaper, pamphlets or booklets (8 percent) (Table 13.1). 
Table 13.1: Percentage of respondents hearing reproductive health messages in the last year, by topic and medium $(n=3223)$

\begin{tabular}{lccccc}
\hline & \multicolumn{5}{c}{ Source } \\
\cline { 2 - 6 } & Any source & Lecture & Radio & Provider & $\begin{array}{c}\text { Newspaper, } \\
\text { pamphlet, booklet }\end{array}$ \\
\hline Any RH information & 63.6 & 47.0 & 31.0 & 39.4 & 8.0 \\
HIV/AIDS & 59.2 & 42.6 & 30.1 & 29.0 & 6.9 \\
Safe motherhood or FP & 52.9 & 36.0 & 25.4 & 29.1 & 5.2 \\
FGC or early marriage & 54.4 & 38.4 & 25.3 & 34.2 & 5.8 \\
\hline
\end{tabular}

While there was considerable exposure to RH messages through lectures, radios and health providers, there was very little interpersonal discussion on the topics (Table 13.2). While HIV/AIDS was the most common RH topic discussed, less than half of the respondents ( 47 percent) had discussed it in the last year. Moreover, respondents were more likely to discuss the topic with their female friend ( 22 percent) than their husband (18 percent). The two least discussed RH topics were condoms (17 percent) and safe motherhood (16 percent). As with HIV/AIDS, respondents were just as or more likely to discuss these topics with female friends than with their husbands. After spouses and female friends, other important discussion partners for respondents were teachers or pastor (14 percent) and parents (11 percent).

Table 13.2: Percentage of respondents who discussed topics in the last year and discussion partners for topics

\begin{tabular}{|c|c|c|c|c|c|c|c|c|c|}
\hline & \multirow[b]{2}{*}{$\begin{array}{c}\text { Discussed } \\
\text { Topic in } \\
\text { Last Year }\end{array}$} & \multicolumn{8}{|c|}{ DISCUSSION PARTNER } \\
\hline & & Spouse & $\begin{array}{c}\text { Female } \\
\text { Friend }\end{array}$ & $\begin{array}{c}\text { Teacherl } \\
\text { Pastor }\end{array}$ & Parents & $\begin{array}{c}\text { Other } \\
\text { Adult } \\
\text { Relative }\end{array}$ & Children & $\begin{array}{c}\text { Members } \\
\text { of Women's } \\
\text { Group's }\end{array}$ & In Laws \\
\hline Any topic & - & 30.8 & 30.7 & 13.9 & 11.3 & 10.1 & 6.7 & 5.7 & 3.1 \\
\hline HIVIAIDS & 46.6 & 17.9 & 22.2 & 10.9 & 6.2 & 5.8 & 3.2 & 4.2 & 1.4 \\
\hline Female circumcision & 32.8 & 12.3 & 13.0 & 9.6 & 4.7 & 1.5 & 1.5 & 3.5 & 1.6 \\
\hline Family planning methods & 32.5 & 17.9 & 11.3 & 5.7 & 3.3 & 2.9 & 1.0 & 3.1 & 1.4 \\
\hline Early marriage & 29.3 & 9.2 & 12.9 & 8.8 & 4.3 & 4.0 & 1.3 & 3.1 & 0.9 \\
\hline Condoms & 16.6 & 3.1 & 8.0 & 3.9 & 0.8 & 1.4 & 2.7 & 2.7 & 0.4 \\
\hline Safe pregnancy & 16.4 & 7.0 & 7.1 & 4.5 & 1.6 & 2.1 & 0.9 & 2.3 & 0.9 \\
\hline
\end{tabular}




\section{XiV. Program Preferences}

Respondents were read a list of classes and asked if they would like to attend a class given on specific topics (Table 14.1). The most popular type of class was literacy (54 percent), followed by HIV/AIDS (41 percent) and business training (39 percent). The majority of respondents said that they could attend classes either once a week ( 45 percent) or twice a week (40 percent); most preferred the morning hours (58 percent) and very few said that they could attend during evening hours ( 3 percent).

Table 14.1: Percentage of respondents reporting that they would like classes in specific topics, by topic $(n=3222)$

\begin{tabular}{lc}
\hline Topic & \\
\hline Literacy & 54.3 \\
HIVIAIDS & 40.5 \\
Business training & 39.0 \\
Agricultural methods & 25.4 \\
Family planning & 23.8 \\
Numeracy & 21.7 \\
Health and hygiene & 21.2 \\
Money management & 18.1 \\
Safe pregnancy / safe motherhood & 13.2 \\
Savings and credit & 8.6 \\
\hline
\end{tabular}

When asked about potential barriers to participation in such programs, competing demands on time seemed to be more problematic than family disapproval. Forty-five percent of women said that they cannot be away from home for more than a few hours per week and 37 percent reported that their workload may not allow them to attend classes all the time. In comparison, 23 percent mentioned that their husbands/parents may disapprove of their involvement. 


\section{Recommendations \& Implications for Programs}

The baseline findings highlighted the diverse needs of rural girls and women in Amhara region. In particular, education appeared to be associated with a number of positive outcomes. Following the baseline study, the Leave No Woman Behind project began, supporting the age-specific education, $\mathrm{RH}$ and livelihood needs of adolescent girls and adult women in rural Amhara. The project focuses on strengthening the literacy skills and knowledge of girls and women, and also addresses their reproductive health and livelihoods needs. The project is innovative in that it seeks to combine literacy, reproductive health and livelihoods interventions toward the improved living conditions and social status of women and girls.

\section{- Opportunities for education and literacy skills for adolescent girls and women}

The baseline study emphasized that school attendance and educational attainment is exceedingly low for women and girls in the area, and that increases in education are associated with positive outcomes for their health and well-being. School attendance among adolescents is higher than among older women, suggesting a possible social change in attitudes toward girls' education and access to schooling. It is recommended that girls be provided increased educational opportunities through bursary support as well as non-formal education. Similarly, literacy and numeracy skills will increase the capacity of older women to engage in livelihood activities and to access reproductive health information, including FP, safe motherhood issues and information on harmful traditional practices. Awareness raising at the community level is also needed in order to promote a supportive environment for girls' and women's education.

\section{- Opportunities for adolescent girls - including married girls - to establish social networks}

Survey findings reveal that adolescent girls have extremely limited social networks and support outside their families. Less than one third of girls aged 10 to 19 had someone to turn to in the event of family or marriage problems, if they needed food, money or a place to stay, or in the event of rape. Absence of social networks likely reflects limited access to information on basic life skills and issues related to reproductive health. Married adolescent girls, in particular, need mechanisms that combat their social isolation and venues through which they can obtain information and resources related to their sexual and reproductive lives. In communities where adolescent girls are married during their early years and expected to take on expanded family responsibilities, social isolation reinforces poor livelihood and reproductive health outcomes. Programs should create opportunities for mentorship and interaction with other girls and women. For example, married girls clubs can be venues through which girls expand 
their social networks, gain access to mentors and, at the same time, access critical life skills and health information.

\section{- Improved living conditions and social status of women within households and communities}

Survey results suggest that women have limited access to resources, including sources of income. Only 15 percent of women have ever worked for pay and 72 percent depend on their husband economically. Interventions including savings, financial literacy, entrepreneurship, and income generation would not only enhance women's skills and income but would also contribute to increased negotiating power within the household. Literacy and non-formal education services could be used as mechanisms to mobilize groups of adolescent girls and women. Adolescent girls and women in the project sites could benefit from livelihood skills in areas such as vegetable gardening and poultry-rearing. In addition, older women could be targeted with savings and micro-credit.

Male involvement is an important strategy in order to enhance the empowerment and should not be overlooked. While target-focused interventions addressing the needs of adolescent girls and women will contribute to "leveling the playing field," males and community members' participation should be promoted through innovative interventions such as 'community conversations.'

- Increased age of marriage for girls and address other forms of harmful traditional practices (HTPs)

Programs to delay early marriage and support girls within marriage are critical. Study findings revealed that the vast majority of marriages were arranged and very few included consent from the bride. Despite modest increases in age at marriage, median age of marriage is still low: 17 years among the 10 to 19 age group. Furthermore, most respondents first had sex within the context of marriage, meaning the timing of first sex and first birth was mainly driven by the timing of marriage. Divorce is a peculiar outcome of early marriage and a clear reflection of mistimed and unwanted marriage. The advantages of delaying marriage in this population include delayed sexual initiation and first birth, as well as allowing girls time to achieve full development and potential.

Interventions in the area of education and literacy have contributed to possible delays in marriage. ${ }^{8}$ Such interventions should be reinforced with community based social change strategies to address underlying determinants of early marriage. Innovative social change strategies such as 'community conversations' have the potential to reduce the practice of early marriage in addition to interventions directed at girls themselves.

8“"Berhane Hewan: A program to support married and unmarried adolescent girls in rural Amhara region, Ethiopia," 2006. Population Council program brief, November. 
Similarly, female genital mutilation/cutting (FGM/C) is another HTP which is still prevalent, with 70 percent of girls aged 10 to 19 having been cut. Both education/literacy and community based social change interventions should be employed as strategies to reduce the practice of FGM/C.

\section{- Increase utilization of $R H$ services, including family} planning

Most respondents were aware of only a limited number of contraceptive methods and use of family planning was low. The study showed that among sexually active women, only 13 percent were using a method. Establishing health posts and strengthening existing health centers in the intervention sites is needed. Moreover, many women perceived that their husbands disapproved of family planning. Education and awareness raising strategies should address male attitudes in addition to targeting women.

\section{- Improved health-seeking behavior and services on safe motherhood for adolescent girls and women}

The study showed that home births were supported by community values with most respondents feeling that the community and their husbands prefer births at home compared to a health facility. Such a practice exacerbates the already poor RH situation. Programs that address safe motherhood issues are vital interventions to save the lives of many girls and women. Obstructed labor, post partum hemorrhage, ruptured uterus, and infection, among others, are major complications of pregnancy and childbirth that lead to maternal mortality and morbidity. Programs should education women on the danger signs related to these complications, establish strong referral linkages, and strengthen existing health facilities to provide emergency obstetric services.

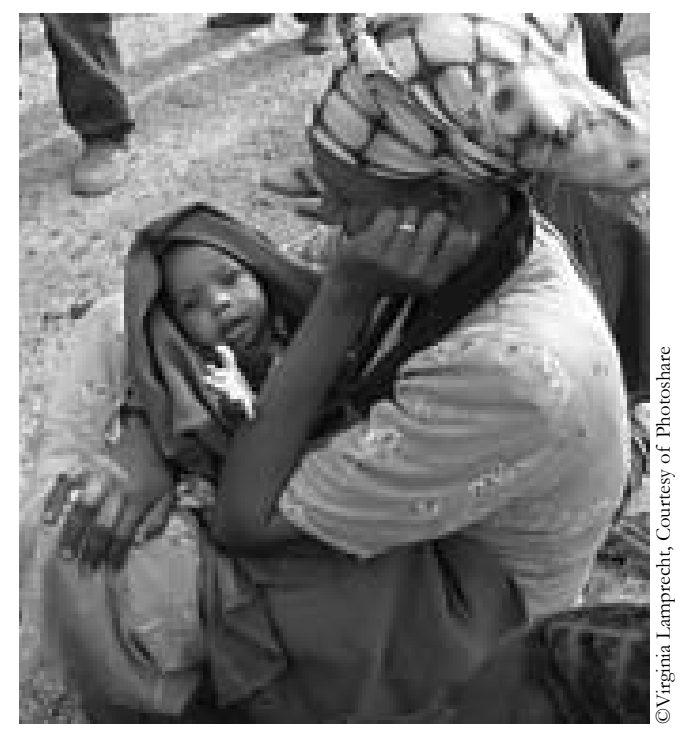




\section{APPENDIX A: STUDY SITES}

List of study sites and population sizes, West Gojjam, Amhara region

\begin{tabular}{lllc}
\hline Woreda & Peasant & Status & Population Size \\
\hline Yilimana Densa & Gonji & Experimental & 8,772 \\
& Debre Mewi & Control & 10,894 \\
Mecha & Rim & Experimental & 9,231 \\
& Ambo Mesk & Control & 8,652 \\
Achefor & Yesmala Jankit & Experimental & 7,476 \\
& Abchekli Zuria & Control & 9,801 \\
\hline
\end{tabular}

\section{APPENDIX B: HOUSEHOLD ASSETS}

Percentage of households possessing specific items, by woreda

\begin{tabular}{lcccc}
\hline Item & $\begin{array}{c}\text { Yilimana Densa } \\
(\mathbf{n}=\mathbf{1 0 8 8})\end{array}$ & $\begin{array}{c}\text { Mecha } \\
(\mathbf{n}=\mathbf{1 0 6 3})\end{array}$ & $\begin{array}{c}\text { Achefor } \\
(\mathbf{n}=\mathbf{1 0 7 2})\end{array}$ & $\begin{array}{c}\text { All } \\
(\mathbf{n}=\mathbf{3 2 2 3})\end{array}$ \\
\hline Kerosene lamp & 91.3 & 95.1 & 98.6 & 95.0 \\
Dwelling in which they & & & & \\
reside & 87.3 & 96.2 & 99.2 & 94.2 \\
Crop land & 79.4 & 82.8 & 93.2 & 85.1 \\
Cattle & 59.7 & 78.9 & 87.5 & 75.3 \\
Corrugated iron roof & 71.2 & 47.2 & 47.7 & 55.4 \\
Bed or table & 47.2 & 50.4 & 57.6 & 51.7 \\
Horse, mule, donkey, or & & & & \\
Oxen & 37.3 & 45.9 & 56.4 & 46.5 \\
Radio & 24.8 & 28.3 & 34.2 & 29.1 \\
Cash crops & 22.7 & 26.3 & 34.8 & 27.9 \\
Pit latrine & 22.4 & 45.0 & 12.3 & 26.5 \\
Electric mitad & 4.2 & 4.3 & 0.9 & 3.2 \\
Electricity & 4.6 & 2.4 & 0.6 & 2.5 \\
Piped water & 1.3 & 2.6 & 0.4 & 1.4 \\
Television & 0.5 & 0.3 & 0.0 & 0.2 \\
Telephone & 0.1 & 0.4 & 0.0 & 0.2 \\
\hline
\end{tabular}



